\title{
Integration of lean accounting techniques and balanced scorecard to evaluate the performance of economic units: An exploratory or applied study in Iraq
}

\author{
Rasha Jasim Ahmed Ebraheem Alobaidy \\ College of Islamic Sciences / Department of Islamic Banking and Finance / University of Iraq
}

\begin{abstract}
Recent technological developments and environmental changes that have occurred in recent decades have affected the economic environment and significantly affected the accounting field, where a large spread of industrial enterprises has emerged, which led to increased competition and complexity of the wishes and needs of customers. The research adopted on the topic of Lean accounting, which recognizes the importance of integration between Lean accounting techniques and sustainable balanced scorecard, and how the application of these techniques will reflect the views. This study aimed to determine the role of Lean accounting. There are many results and, more importantly, there is an integral relationship between Lean accounting methods and sustainable balanced scorecard views, reflecting the use of meager methods (value stream, continuous improvement) in a positive way on sustainable scorecard views, and as a result of achieving Balanced and sustainable strategic performance. The study concluded some recommendations such as activating the use of the value principle of accounting Lean was higher to eliminate waste and loss, as well as to maximize the benefits of economic units by finding solutions to problems and obstacles facing the production process.
\end{abstract}

\section{Corresponding Author:}

Rasha Jasim Ahmed Ebraheem Alobaidy,

College of Islamic Sciences / Department of Islamic Banking and Finance / University of Iraq

Email: rasha_9484@yahoo.com

\section{Introduction}

In general, accounting science has significant progress and remarkable development due to the industrial revolution, which requires us a lot of research and response to obtain information in an easier and smoother way, to help us make the right decision in the world of management accounting and business administration. For these reasons, it is necessary to respond effectively and move from traditional accounting systems to modern accounting systems, such as Lean accounting, in order to identify and delete activities that add value to them. This helps to reduce production costs, maximize profits and achieve the desired goals of the company. Nowadays, the use of lean accounting is especially important for developing countries, which are used to create value for the customer, promote lean in operating activities, achieve a competitive advantage in the market, and eliminate waste and waste that occurs in production processing [1].

Technological development is the basis for the development of human civilization throughout the ages [2]. The history of civilization consists largely of a mutual interaction between two forces that support and control man at the same time, namely technology and society. Technological development has had an impact on the aspects of public life and productive activities; especially that progress in manufacturing methods is a mirror of that technological development. Although technical development is in the service of society, society is a tool to implement it and activate all its advantages through it. Thus, the impact of productive activities on the technical development has had an impact on cost accounting by responding to many practices or techniques represented by cost management techniques [1]. 
With the advent of Accounting Lean, and the competition it has shown in light of the technological developments of the last century, changes in the various economic areas of the Lean production system, which deals with the main issues that are one of the basic principles of this system, which is to reduce Wastage, and continuous improvement [2].

Lean accounting in terms of accounting means control, measurement and management methods that reflect the truth of rational thinking and good practices, and it makes the best decisions through its tools tight, understandable, correct and reliable information, and it works to save time and money by eliminating most of the losses associated with traditional accounting, accounting was one of these variables, which called on all those interested in the field of cost accounting to work on the development of traditional methods of accounting in particular, the main goal of Lean accounting is to eliminate the loss associated with the production, operation, and accelerate processes, and reduce the incidence of mistakes [3].

With the emergence of this type of accounting, it follows a new approach, which increases the interest through its connection with the culture of rationalization, and work to measure the financial impact to improve the economic units in the production system, and the flows of value provided; it is the new way of calculating costs [4].

\subsection{Problem statement}

The spread of globalization, its expansion in all local and global fields, and the opening of markets to the world as a small village, which increased the intensity of competitiveness among economic organizations and units, in addition to raising awareness and awareness among senior management of the importance of cost and reduce, has had a significant impact on Strengthening and increasing competitiveness, as well as increasing consumer awareness and demanding a certain quality level, has prompted industrial organizations in Western countries to adopt modern methods and methods to reduce their costs.

Several previous studies have revealed a gap between the scientific development of Lean accounting methods and the reality of their application in working life. The results of these studies also show that traditional methods continue to dominate the administrative accounting systems applied on the ground to be used more than modern methods, which has negative repercussions on Meet the information needs of organizations The research problem lies in the fact that many economic units are still afraid to enter the modern world of accounting (for reasons of their inability to control the markets and pricing decisions and thus the inability to control costs along with the adoption of traditional ways to reduce costs), and therefore The failure of existing economic units to implement Lean accounting tools and balanced scorecard has led to the loss of important information regarding balanced strategic performance and consequently the loss of sustainable competitive advantage.

\subsection{Research questions}

The main question of this study is: "What is the extent of integration between Lean accounting techniques and balanced scorecard to assess the performance of economic units in Iraq?"

This main question is subdivided into the following sub-questions:

1. How to achieve balanced and sustainable strategic performance?

2. How far are Iraqi economic units applying Lean accounting techniques?

3. What are the obstacles to the use of modern Lean accounting methods by the Iraqi economic units?

4. Do Iraqi economic units apply balanced scorecard to evaluate performance?

5. What are the dimensions of the balanced marks card in the Iraqi economic units?

\subsection{Research objectives}

The main objective of this study is: "To show the extent of integration between Lean accounting techniques and balanced scorecard to assess the performance of economic units in Iraq." 
This main objective is subdivided into the following sub-objectives:

1. Achieve balanced and sustainable strategic performance.

2. To know the extent of the application of Iraqi economic units Lean accounting techniques?

3. To study the balanced scorecard for the performance evaluation?

4. To identify the obstacles to the use of modern Lean accounting methods by the Iraqi economic units?

5. To determine the dimensions of the balanced marks card in the Iraqi economic units?

\subsection{Research hypotheses}

This study has the following two null hypotheses as indicated below:

H0: The Lean accounting techniques and balanced scorecard and integration between them show the impact of the performance of economic units on the modern environment and their interaction.

H1: The use of a combination of Lean accounting techniques together has a more positive impact on the organization if a particular technology is used alone because of the complementarity and interrelationships between the technologies.

H2: The objectives of Lean accounting techniques and balanced scorecard are fully consistent with the objectives of the organizations in the modern environment in terms of reducing costs, improving quality, achieving customer satisfaction, growth and continuity in the market.

H3: The integration of continuous improvement and value stream as two tools of Lean accounting with the Balanced Scorecard provides the appropriate information to help achieve a balanced and sustainable strategic performance

\subsection{Research significance}

Since the aim of the research is to present the techniques of Lean accounting and balanced scorecard and to demonstrate the extent of their integration and interdependence, the importance of research lies in the importance of these techniques in business organizations and their impact in compensating organizations for some of the levers that have escaped their hand in light of intense competition in the modern environment. As well as the importance of the research is to provide a theoretical framework showing the integration between Lean accounting tools and balanced strategic scorecard and the application of this framework to show its impact on performance and development of economic business.

This research focused on trying to figure out the Integration of Lean Accounting Techniques and Balanced Scorecard to Evaluate the Performance of Economic Units in Iraq. Previous studies in Lean accounting are few in Iraq. In addition, Lean accounting studies are hardly in the Arab world. For these reasons, it is extremely important to increase the volume of studies on Lean accounting especially for Economic Units in Iraq.

\subsection{Research method}

A descriptive approach was adopted in the preparation of research through reference to theses, theses, scientific research and Arabic and foreign books, where it is it requires for extrapolation of lean accounting literature and logical analysis of assumptions that can be applied to lean accounting.

\subsection{Previous studies}

Samadet. al. (2017) proposed to clarify the role of modern accounting methods such as lean accounting to support and improve resource use. This helps create value for the organization, eliminate activities that do not add value, and eliminate deficiencies in traditional accounting methods by applying modern accounting methods such as Lean accounting. The qualitative research methodology was used to study the types of accounting methods in Swedish industrial companies. The results showed that the accounting approach of these companies becomes more oriented towards the use of modern accounting methods because traditional 
accounting methods are not suitable for the process of lean production. Finally, they recommended expanding research to explore the relationship between Lean accounting principles and cost accounting methods by creating value and linking that value to the value stream in order to provide a clear view of the company's future improvement [5].

Al-Rahimi (2016) has the advantages of studying the philosophy of thin accounting and identifying its tools and principles. This helps clarify the difference between the use of traditional accounting methods and the Lean accounting method at different levels such as the difference between them in reducing costs, their tools, and their roles in lowering the cost of production at JIC. Al Rahimi. Use the descriptive analytical method to illustrate the results. The results showed that Lean accounting has an important role in reducing costs in the Jordan Industrial Corporation, which statistical results showed a value (.050.05) compared with other traditional methods. In addition, they recommended that JTIC management use a lean accounting application to ensure the success of this application [6].

Hijazi (2015) has the merits of studying the extent to which lean accounting is applied in Jordan Industrialization Corporation. Furthermore, they studied the factors that impede the poor application of accounting at JIC. Hijazi. Liquid is used as a tool to collect information from these companies. In addition, they used a descriptive analysis method to illustrate the results of these respondents. The researcher has come to many conclusions, including, there are some elements that help to apply Lean accounting within the systems of these companies, such as economic factors and cultural factors. In addition, they showed that most industrial companies use an accurate and detailed method for estimating different types of information that reflect employee performance, which helps to implement a decentralized management system. All this will help to facilitate the application of lean accounting in these companies. Finally, they recommended that Jordanian industrial companies focus on a simple accounting method to increase profits rather than using traditional accounting methods [7].

Pentlickl (2014) has the advantages of exploring elements that facilitate and restrict the application of Lean accounting methods and tools in different types of companies. I conducted a face-to-face interview with the CIOs, CEOs and senior CFOs of these companies. Data were collected through interviews with senior leaders (CEOs, CIOs, Deputy COOs, CFOs and General Managers) in 617 SMEs. The results of the study showed that all SMEs should establish their own and structured ways of applying lean manufacturing and free accounting. In the end, they recommended that the manufacturing company use Lean accounting at all stages of productivity, which is a key philosophy of work and production [8] .

\section{Lean accounting}

Accounting has undergone great developments over the years from being an art to recording some financial transactions of an individual entrepreneur to an accounting system, then an administrative and calvary system that provides internal and external reports to management, and then has evolved, especially in recent decades, to an information system that responds immediately and reflects objective information. It is of relative importance to serve in making several administrative and accounting decisions within the project. This has been done through the implementation of some practices and procedures that provide data and information to management in a timely and timely manner.

Lean accounting can be defined as: Lean accounting is a modern accounting approach that reflects meager practices and meager thinking by increasing the usefulness of work and improving decision-making by providing comprehensible and accurate information. In addition, it is used to eliminate waste and loss created based on traditional accounting systems. This leads to increased profits of the economic unit. Researchers have defined Lean accounting as a modern management accounting system that aims to increase profits, seek perfection, eliminate waste and loss, and deliver products to customers without delay. In addition, it aims to achieve the desired corporate goals, which help corporate managers by making appropriate management decisions at the right time. Ultimately, this reduces costs and increases profits [9]. 
Lean accounting has been defined in two basic dimensions: Brewer \& Kennedy). The first is cost analysis by the value stream. The value stream includes all value-added activities and those that have little or no value but are already within processes and deplete resources. The second dimension is the Agile Income Statement or, which shows the effects of inventory and actual costs without adjusting for deviations - that is, because income is usually considered - as well as other details [10].Maynard Ross pointed out that agile accounting is a synthesis of skills and that accountants are keen to exploit them because they represent opportunities for success for them [11].

Horngren defined Lean accounting from its cost point of view as the way that supports the creation of value for customers by calculating the full costs of value streams and not calculating the cost of specific products or individual sections and thus will eliminate all types of wastage in activities. Lean accounting is a method that aims to support and encourage agile manufacturing in order to avoid impediments and false signals. As well as there are changes in both product costs and operational control are also required when moving to a valuebased agile manufacturing system [12].

The fundamental essence of the accountant presence in economic units is not only to record financial events, but over time and the development of science and technology has also evolved the functions of the accountant has risen to be an integrated system that equips management with the necessary information, appropriate and necessary in time to make many critical decisions concerning the future Economic unity and the nature of its activity, therefore, the modern practices applied by accounting and in all branches of financial, administrative and cost different from some aspects of traditional practices [10].

Traditional accounting refers to manufacturing principles that have focused on product production to achieve economies of scale through long periods of production of a product as in stages or production orders. This process is governed by a wide range of regulations, instructions and documents imposed by external auditors and regulators. While Lean accounting focuses on making the product at a specific time for the customer and the unit, in fact traditional systems are not the wrong way to work, but are designed to support mass production. Lean accounting sheds the assumption that mass production is required. It also eliminates the need for procedures to preserve the many and complex stockpiles and ways of disbursement, retention, registration and control. This is the main difference between agility and the traditional approach to accounting. Therefore, you need graceful accounting for several reasons, including [13]:

- Provide clear, correct and timely information to make agile changes in its entirety organized and also to make changes in decision-making leading to increased attention to the principle of customer retention, development, profitability and cash flow

- Use agility tools to remove waste sources resulting from excessive accounting processes in control and other procedures

- Protecting the culture of agility by encouraging staff in the unit and their culture, providing actionable information and promoting continuous improvement at all levels of the unit.

\subsection{Principles of lean accounting}

Lean accounting derives its principles and foundations from the perspective of agile thinking can be summarized by saying "use less than possible resources of the unit while improving production or service" The following are the five principles underlying Lean accounting and whose tools directly depend on these principles [10].

Accounting business simple and lean: Some of the accounting operations contain one or more types of waste, which is divided into two main parts, the first waste cannot be eliminated in the short term and the second is the most common and can be dealt with and eliminated by the use of all the methods of Lean accounting applied to accounting operations, where the waste is reduced and prevented However, this requires the application of these tools and methods properly and well and appropriately with the presence of effective and continuous control to achieve the complete elimination of all sources of waste within the unit, the 
presence of competent and trained staff to deal with these tools - tools Agility - result in our application Fit for agility within the unit [14].

Accounting processes that support lean transformation: Nick Katkopointed out that Lean accounting reports and all methods and activities and the information contained in it work to improve continuously within the unit, as agile reports reflect the financial and non-financial data and information of value streams within the unit and not for individual products, processes or activities, and Lean accounting focuses on understanding and measuring How to create value for customers by using all the information to build relationships with customers, product design, pricing and optimization [13].

Clear and timely communication of information: David Painopoints out that Lean accounting provides financial and operational reports that are understandable, clear and easy to use and any user inside or outside the unit can understand its contents and the information contained therein. The information in the income statement provides comprehensive and easy information at the same time and is not more difficult than disclosing the budget of a particular family. They are easy and do not contain misleading and confusing information about standard costs.

Planning and budgeting from a lean perspective: Agile planning begins with the publication of the Hoshinpolicy and passes through the SOFP (Sales, Operations, Financial Planning) [14].

Strengthen internal accounting controls: There are many methods and tools that work on internal control, such as the tool "matrix elimination of transactions" This is an essential tool that works to eliminate all unnecessary traditional processes and distinguish the processes and all without compromising the power of financial and operational control.

\section{Balanced scorecard}

The development in the work of the business organizations and the increasing intensity of competition require the departments of those organizations comprehensive attention to work and thus cannot adopt financial and accounting standards and indicators only to express this inclusiveness. Therefore, it was necessary to overcome these challenges through the transition of business organizations in their thinking from the industrial age to the knowledge age where inclusiveness and focus on multiple aspects of performance gives the organization more ability to continue and compete and satisfy customers and various stakeholders.

The Balanced Scorecard came as a result of the convergence of several currents in the administrative and financial thinking. It is an entrance that is in line with the development in the various aspects of management. Norton \& Kaplan is the basis for the emergence and development of the concept of balanced scorecard, which coincided with the development of many concepts during the nineties of the last century [15].

The emergence and development of the Balanced Scorecard came through the combined efforts and desire of leading organizations in the application of these new ideas without hesitation as important ideas that give positive returns to the work of business organizations [16].

The Balanced Scorecard is defined as the translation of the mission and strategy of the business unit into concrete goals and metrics through the interaction of four axes: financial, customer, and Kaplan and Norton, 1996.

The Balanced Scorecard is one of the contemporary management tools and one of the most important set of administrative concepts based on a clear philosophy in defining the strategic direction of the organization and measuring the level of progress in performance towards achieving the objectives. A balanced scorecard is a conceptual framework for translating the Organization's strategic objectives into a set of performance indicators.

The Balanced Scorecard provides a clear view of the business organization on its current status and future. It is a premise based on the premise that measurement is a prerequisite for strategic management that should receive considerable attention. What cannot be measured cannot be clearly managed [17]. Research and 
studies have identified the importance of a balanced scorecard with a set of points that can be summarized as follows:

- Acts as the cornerstone of the current and future success of the Organization in contrast to the traditional financial standards that report what happened in the past without indicating how they can be used to improve performance in the future.

- Address the shortage of traditional management systems in the sense that they address the inability of these systems to link the organization's long-term strategy with its actions and short-term activities.

- Clarifies vision, improves performance, sets targets and provides feedback to strategy.

- Be able to diagnose and identify in practice new areas that should characterize the organization to achieve consumer and organizational goals.

- Assist the organization by focusing entirely on what needs to be done to increase performance progress.

- The Balanced Scorecard maintains financial standards as an important summary of business and management performance and highlights a more general, interactive and interrelated set of metrics between clients, internal processes, employees and system performance for long-term financial success.

\section{Evaluate performance from Lean accounting perspective}

The implementation of agile philosophy requires the introduction of new performance appraisal procedures that allow oversight and lead to continuous improvement of operations [10]. These actions, which reflect agile principles, will be part of the visual management techniques used by agile units and create a link between the business cell and the value stream on the one hand, and the objectives and strategy of the unit on the other. Performance appraisal based on agile thinking cannot be based solely on financial indicators [14]. It must be supported by operational indicators as well, and must be done at the level of the Worker Cell and Stream value, so that the integration of the strategy of the unit with the ongoing processes, and the involvement of all employees of the unit in the process of evaluation in order to progress towards continuous improvement of all currents and all Levels. Performance evaluation in agile units focuses on three main areas [18]:

Worker cell: The purpose of a Worker Cell is to produce high quality products or services in a continuous flow ready at the time requested by the beneficiary. The researcher believes that this applies to economic units as well. In each stream within the economic unit there is a work cell composed of a team of workers and administrators working together to achieve customer service related to them.

Value streams: The Value Stream team must have the following objectives

- Deliver the products to the customer as soon as possible

- Getting the lowest cost of the product

- Increase profitability and reduce inventory

The results of these indicators should be reported on a weekly basis to maintain tight control over the operations within each stream.

Management visual: Performance evaluation requires a visual presentation of financial and non-financial indicators. A square panel called the (Scores Box) is usually used for this presentation, which contains a summary of the value stream with its operational performance, financial performance and how to use energy [19]. Consequently, decisions are made using information provided by the Performance Fund containing performance indicators for value streams that are usually updated weekly and used by the Continuous Improvement Team to identify areas for improvement and monitor progress [18]. 


\section{Conclusion}

The Lean accounting techniques and balanced scorecard and integration between them show the impact of the performance of economic units on the modern environment and their interaction. The use of a combination of Lean accounting techniques together has a more positive impact on the organization if a particular technology is used alone because of the complementarity and interrelationships between the technologies. The objectives of Lean accounting techniques and balanced scorecard are fully consistent with the objectives of the organizations in the modern environment in terms of reducing costs, improving quality, achieving customer satisfaction, growth and continuity in the market. Based on the data collected by the researchers, , the following results were obtained:

1) There is a role for Lean accounting in reducing production costs in economic units.

2) There is a role in adopting Lean accounting principles in reducing production costs in economic units. This result also showed the importance and relative importance of adopting Lean accounting principles in reducing production costs.

\section{Recommendations}

Depending on the results, the researchers recommend:

1) The need for senior management and executive departments in industrial companies to increase the activation of Lean accounting principles to increase the flow of value in operational activities, and identify and encourage activities that add value to products, and delete activities that do not add value to products.

2) To activate the use of value principle in lean accounting in a higher way, to eliminate waste and loss and maximize the benefits of the company, in order to reduce production costs.

3) Activate the use of the principle of value flow in Lean accounting in order to determine the total flow of all production activities and work in an integrated manner, and the development of daily reports per hour to increase the ability to detect and solve obstacles. This leads to lower production costs.

4) Relying on the principle of material flow and material withdrawal, linking this principle with the needs and desires of customers to provide competitive products in quality and price.

5) Increase the level of employee participation in the development of company plans to improve quality and performance, and take their views and suggestions regarding production processes, and value flow.

\section{References}

[1] k. Al-Dulemi, " Role of Lean Accounting in Reduction Production Costs in Jordanian Manufacturing Corporation. Research Journal of Finance and Accounting, Vol.9, No.16.," 2018.

[2] M. F. Shojaa, "THE ROLE OF LEAN ACCOUNTING IN COST REDUCTION. AN APPLIED STUDY AT FINE COMPANY FOR HYGIENIC PAPERS (master thesis). Middle East University," 2015.

[3] K. Okpala, " Lean Six Sigma Methodologies and Organizational Profitability: A Review of Manufacturing Smes in Nigeria. American Journal of Industrial and Business Management.3,(13) , 573-582," 2013.

[4] L. W. \&. L. A. S. Stephen, " "Using Dyn.amic value Streem mapping and lean accounting box scores to support lean implementation:". Mankato. USA.," 2010.

[5] M. A. S. Y. \&. O. K. Samad, "Value Creation with Lean Accounting. Sekaran, U.,Bougie, R.,(2010). Research Methods.For Business: A Skill- Building Approach (5th ed). New York: John Wiley\& Sons Inc.," 2017.

[6] L. F. Rahimi, " lean accounting tools and their role in reducing the cost of production in Jordanian 
industry companies. (Field study from the point of view of cost accounting), Unpublished Master Thesis, Irbid National University, Jordan.," 2016.

[7] A. Hijazi, "'The Extent of Application of lean Accounting in Jordanian Manufacturing Corporation".Master Thesis, Yarmouk University, Jordan.," 2012.

[8] J. Pentlicki, " Barriers and success strategies for sustainable lean Performance, Butterworth-Heinemann, Oxford.," 2014.

[9] H. Kazim, " "A Proposed Model for the Application of lean Accounting in Public Companies for Electrical Industries". Journal of the Center for Studies of the Kufic, 1 (35): 238-224.," 2014.

[10] F. \&. B. P. Kennedy, " Lean accounting: what's it all about? Strategic Finance, November, 27-34.," 2005.

[11] R. Maynard., "Reflections on a lean accounting project, BMA Inc, http://www.maskell.com/lean_accounting/subpages/lean_accounting/articles/refl ections_on_a_lean_accounting_project.pdf," 2008.

[12] C. T. a. F. G. a. D. S. M. Horngren, " Cost Accounting AManagerial Ephasis, 14th ed., Prentice - Hall, Inc., New Jersey.," 2012.

[13] M. H. N. R. Peter Hines, "From Strategic Toolkit to Strategic Value Creation: A Review of the Evolution of Contemporary Lean Thinking" in the International Journal of Operations \& Production Management, Vol 24, (Peter, Matthias, Nick:20," 2004.

[14] B. \&. B. B. Maskell, " Lean accounting: what's it all about? Target Magazine, 1, 35-43. Book of Proceedings," 2006.

[15] a. N. Kaplan Robert, " balanced scorecard: Measures that drive performance, Harvard Business School Publishing Corporation, Boston, MA.," 2005.

[16] S. a. N. D. ,. Kaplan, " The Balanced Scorecard Measures Translating Strategy in Action, Harvard Business , Review.," 1996.

[17] R. Robinson, " Balanced Scorecard, Computer World, Vol. 34, Issue4," 2000.

[18] B. \&. K. F. Maskell, "Why do we need lean accounting and how does it work? The Journal of Corporate Accounting \& Finance, March/April, 59-73.," 2007.

[19] E. C. \&. K. M. Richard, " Lean Accounting-Fad or Fashion. Retrieved from http://www.sedsi.org/2008_Conference/proc/proc/p070921001.pdf," 2007. 